\title{
It's time to re-acknowledge the differences
}

\author{
D. E. Tripoloni ${ }^{1}$ - M. I. Canaro García ${ }^{1}$ (D) F. Cassani ${ }^{1}$ (]) M. Zanni ${ }^{1}$ (])
}

Received: 7 August 2021 / Accepted: 24 August 2021 / Published online: 30 September 2021

(c) The Author(s), under exclusive licence to Springer-Verlag France SAS, part of Springer Nature 2021

\section{Dear Editor,}

We have read with great interest the article by Martín Duce et al. [1] showing a low rate of late recurrences after Shouldice repair, which are higher in medial hernias (about 5.1\%) compared to lateral ones (about 1.3\%).

The authors also propose some quality criteria for the inclusion in meta-analyses of articles on inguinal hernioplasty reaching "a basic standard pattern with which to reliably evaluate recurrence results and to compare them with each other".

We would like to propose as another quality indicator the separate report of the results in lateral and medial hernias just as Martín Duce et al. did. In our opinion, the difference in recurrence rates between patients with pure primary lateral hernias and those with medial or mixed hernias should not be ignored, at the risk of continuing to perform mesh repairs without knowing its real benefit for those patients or minimizing the risk of recurrences in the latter ones.

Some authors who have addressed this issue [2,3] found approximately twice the risk of recurrence in medial and mixed hernias and, as our recent review, [4] shows, those "mesh vs non-mesh" studies that performed subgroup analysis have not demonstrated the advantages of prosthetic repair in pure lateral hernias.

There are anatomical reasons that explain the increased risk of recurrence of medial hernias: the high intersections

D. E. Tripoloni

dtripoloni@hotmail.com

M. I. Canaro García

mercanaro@gmail.com

F. Cassani

fedecassani91@gmail.com

M. Zanni

mariana.zanni123@gmail.com

1 División Emergencias, División Cirugía General,

Sanatorio "Dr. Julio Méndez", Avellaneda

551, Ciudad Autónoma de Buenos Aires,

República Argentina of the external oblique and transversus abdominis muscles and its aponeurosis to the rectus sheath increase the tension in the suture line of tissue repairs; furthermore, it may be difficult to achieve sufficient overlap and secure fixation of the mesh at the medial area of the defect (close to the pubic bone), so its retraction may cause recurrences even after open prosthetic repairs.

These factors have been considered in all of the numerous classifications on the types of inguinal hernias that, paradoxically, are left out in most articles on hernioplasty.

Counting on this evidence, we believe that (paraphrasing Kurian et al. [5]) it is time to re-acknowledge the differences.

\section{References}

1. Martín Duce A, Lozano O, Galván M et al (2021) Results of Shouldice hernia repair after 18 years of follow-up in all the patients. Hernia. https://doi.org/10.1007/s10029-021-02422-8

2. Kald A, Nilsson E, Anderberg B, Bragmark M, Engström P, Gunnarsson U, Haapaniemi S, Lindhagen J, Nilsson P, Sandblom G, Stubberöd A (1998) Reoperation as surrogate endpoint in hernia surgery. A three years follow-up of 1565 herniorrhaphies. Eur J Surg 164:45-50

3. Burcharth J, Pommergaard HC, Bisgaard T, Rosenberg J (2015) Patient-related risk factors for recurrence after inguinal hernia repair: a systematic review and meta-analysis of observational studies. Surgical innovation 22:303-317

4. Tripoloni DE, CanaroGarcía MI, Cassani F et al (2021) Mesh repair for lateral inguinal hernias: a non-evidence-based practice. Hernia. https://doi.org/10.1007/s10029-021-02423-7

5. Kurian A, Gallagher S, Cheeyandira A et al (2010) Laparoscopic repair of primary versus incisional ventral hernias: time to recognize the differences? Hernia 14:383-387

Publisher's Note Springer Nature remains neutral with regard to jurisdictional claims in published maps and institutional affiliations. 